5. Science Brief: Omicron (B.1.1.529) Variant, Dec. 2, 2021. Centers for Disease Control and Prevention. URL: https://www.cdc.gov/coronavirus/2019ncov/science/science-briefs/scientific-brief-omicron-variant.html

6. Potential Rapid Increase of Omicron Variant Infections in the United States, Dec. 20, 2021 Centers for Disease Control and Prevention. URL: https://www.cdc.gov/coronavirus/2019-ncov/science/forecasting/mathematical-modeling-outbreak.html\#ref04

7. Karim S. S A., Karim Q.A., Omicron SARS-CoV-2 variant: a new chapter in the COVID-19 pandemic. The Lancet Infectious Diseases. December 03, 2021. DOI: https://doi.org/10.1016/S0140-6736(21)02758-6

8. Прогноз розвитку епідемії COVID-19 в Україні на 22 грудня 2021 року -4 січня 2022 року («Прогноз РГ-58»). Національна академі наук України. URL: https://www.nas.gov.ua/UA/Messages/Pages/View.aspx? MessageID $=8551$

9. Kiianytsia V.V., NEW VARIANTS OF THE SARS-COV-2 VIRUS AND THEIR IMPACT ON THE EPIDEMIC PROCESS SCIENTIFIC PROGRESS OF MEDICINE AND PHARMACY OF THE EU COUNTRIES. (Czestochowa, Republic of Poland, April 23-24, 2021). Czestochowa: Polonia University in Czestochowa, 2021. 192-196

DOI https://doi.org/10.30525/978-9934-26-182-4-47

\title{
THE ROLE OF HUMAN POTENTIAL AS A SOCIO-MEDICAL CATEGORY FOR THE DEVELOPMENT OF A POWERFUL STATE
}

\author{
Korolenko V. V. \\ $M D, D S c$, Deputy Head \\ State Service of Ukraine for Medicines and Drugs Control \\ Kyiv, Ukraine
}

Human potential is a set of opportunities of society, the state and individuals in the use of human resources and productive human traits (business, social, moral, spiritual) for any socially useful activity. In most theoretical approaches, it is considered mainly at the level of civilization and macroeconomic and is interpreted as the main driving force of economic growth [1].

Structurally, human potential includes several components (socioeconomic, socio-cultural, activity and socio-demographic), of which sociodemographic potential has directly the socio-medical nature. It covers 
quantitative and qualitative characteristics of the population (quantity, life expectancy, health status, age and gender balance, level and quality of education). At the same time, other components are indirectly related to the state of health of the population. In particular, the socio-economic potential that reflects the characteristics of welfare and employment (average income, degree of social inequality, working conditions, characteristics of supply and demand in the labor market) is a reflection of the potential of the public health as a health care subsystem. Activity potential, which testifies to innovation activity, ability to creativity and the degree of its implementation, reflects the implementation of innovations in health care practice, the level of transfer of medical biotechnology. Socio-cultural potential that includes the sustainability of cultures, traditions, level of cultures, development in general, values and peculiarities of the mentality of the population, is also the basis for compliance with public communication in the field of public health [1].

Human potential in a post-industrial society is seen as the highest value and important strategic resource, which is the basis for understanding the need for its effective formation, preservation and rational use in order to grow any socioeconomic system. Realized human potential, valuation of the capabilities and abilities of the population and their ability to generate income form human capital [2].

Human capital must be accumulated in the country for a scientific and technical breakthrough and transition to a new technological paradigm [8].

The main reasons for the selectivity of the world among the advanced countries with post-industrial advanced economies - low quality and cost of national human capital, low quality of life, underdeveloped public institutions that do not provide sufficient conditions for 5th, 6th and 7th technological paradigm. That is why not all developing countries will be able to enter the developed world [3]. According to OECD experts, only about 5\% of developing countries will join the number of developed countries in the future [5,7]. The rest will remain in the "reception" of the technologically progressive world, or even in the "reception" will not get [3].

The founder of bioeconomics, Ukrainian demographer Sergiy Tomilin, in his works proved the need to "introduce the principles of economic thinking in the field of biological phenomena." He showed how barbarically irrational human life has been consumed for centuries, what insignificant results, what a miserable "culture" it has produced as added value, and how incomparably better results can be obtained by applying economic principles of saving to "organic capital". [4]. According to WHO experts, lack of health or negative trends in public health destroy potential, create despair and lead to depletion of resources [6]. 
Thus, building a prosperous state requires investment in health care and the formation of long-term policy trends on "health in all policies", which will ensure the development of the relevant components of human potential.

\section{References:}

1. Звонар В.П. Людський потенціал. В: Енциклопедія сучасної України. https://esu.com.ua/search_articles.php?id=59917

2. Мартинова Л. Б. Людський потенціал та його значення у соціально-економічному розвитку країни. WORLD SCIENCE. 2016. № 2(6), Vol.2. C.29-32

3. Розвиток людського капіталу: на шляху до якісних реформ. Центр Разумкова. К., «Заповіт»: 2018. 368c.

4. Томилин С. А. Демография и социальная гигиена. М.: Статистика, 1973. 312c.

5. Johansson Å., Guillemette Y., Murtin F. et al. "Looking to 2060: Longterm Global Growth Prospects" OECD Economics Department Working Papers, no 3. Paris: OECD. 2013.

6. Review of social determinants and the health divide in the WHO European Region. Final report . WHO, 2013. 234 p.

7. Rewizorski M. G20 and the Development of a New Global Governance Mechanism. International Organisations Research Journal. 2017. Vol. 12, № 3. P.32-52. DOI: 10.17323/1996-7845-2017-03-32

8. Simon S. Kuznets. In: National Academy of Sciences. Biographical Memoirs. 2001. Vol. 79. https://www.nap.edu/read/10169/chapter/13. 